\title{
Building Back Better: Business Contributing to a New Economic Paradigm
}

\author{
Katherine Trebeck*
}

\begin{abstract}
The sort of growth cultivated in the last few decades has come without sufficient regard to its quality or distribution. In business, excessive focus on shareholder value and short-term objectives is problematic for social justice and sustainability. Benefits are failing to 'trickle down' and environmental costs grow, becoming more apparent every day. This article explores a New Economic Paradigm that involves upstream change via systemic shifts; delivering social and environmental outcomes from the outset rather than ameliorating or mitigating damage caused by current structures. Businesses can be facilitator, enhancer and deliverer of such change. To illustrate this, this discussion considers how and when businesses can advance safe and just development in terms of local economies; work; and quality rather than quantity of output. It reflects on the role of the state in galvanising effective contribution of business, for example, by inculcating new horizons and incentives; creating widened goals; and reconstituting business.
\end{abstract}

\section{Introduction}

There have been many pronouncements that this 'crisis shouldn't go to waste' - the thinking being that the financial recession represents a discontinuity in which (and with which) to generate change in the way the economy is structured. The need for change could hardly be greater - multiple and interlocking challenges facing the world include breaching environmental limits (Rockström et al. 2009) and rising levels of inequality (Watkins 2013; OECD 2012). While some call for 'economic recovery', the alternative is to Build Back Better. ${ }^{1}$ Returning to business as usual (Resolution Foundation 2012; Pennycook and Whittaker 2012) - a system that created an unsustainable spiral of consumption, inequality, short-termism and alienation - would certainly be a waste.

Rather than dwelling on current challenges, ${ }^{2}$ this article explores how Building Back Better demands rethinking business ${ }^{3}$ practice. It goes beyond incremental increases in narrow economic metrics (namely GDP) (Johnson 2011: 14; United Nations 2012) and away from current systems (Gazibara and Chapple 2011, cited in Coote 2012: 13; Hillier and Castillo 2013;
Gus Speth, cited in Schwartz 2010) based on profit and accumulation towards quality of growth; environmental sustainability; living well; and sharing benefits.

Businesses can be facilitator, enhancer and deliverer (and of course blocker) of this change. Constructive contribution will not come about via natural evolution: pursuit of a New Economic Paradigm (NEP) confronts economic orthodoxy and many prevailing business practices. This article briefly explores what it is that really needs to grow (or decline) and the NEP that encapsulates this. It considers the nexus between a reconceptualised business role and selected elements of an NEP. By way of illustration (rather than prescription), it will consider how and when businesses can advance safe and just development via:
- Local economies;
- Work;
- Quality rather than quantity of output.

New practices are already appearing that illuminate the nature of change needed - from the circular and sharing economy movement to 
deliberate rather than incessant consumption; from the emergence of new organisational forms which pursue a range of goals to relocalisation of economic activity. There are contextual factors and regulatory actions that might compel or encourage further change. To enhance such shifts the state has a role in (inter alia) galvanising the most effective contribution of business, for example, by inculcating:

- New horizons and incentives;

- Widened goals;

- Reconstituting business.

Inevitably this short article offers only a glimpse of the type of change needed. It is far from a complete picture of substantial, complex and still-emerging matters. It does, however, show that an NEP will entail that businesses operate in a range of new ways with widened objectives.

\section{Why a new conception of 'development'?}

'I don't believe that the solutions in a society will come from the left or the right or the north or the south... [Change] will just spread... It will be so natural.'

Karl-Henrick Robert

It seems that now we are entering a period of diminishing marginal benefit - if not increasing harm - from the sort of growth currently pursued. In most advanced industrial countries median wages have stagnated (Nadal 2012). While inter-national inequality is declining, intra-national inequality is increasing: 'nations are growing closer, and classes are growing apart' (Therborn 2011, quoted in Beck 2013); see also Fuentes-Nieva and Galasso (2014). Inequalities weaken social cohesion and trust; they erode a sense of community; produce more crime and violence; result in worse health, education and general wellbeing; and generate economic instability (Wilkinson and Pickett 2009; Marmot 2004: 14). The BMJ (British Medical Journal) states 'what matters in determining mortality and health in a society is less the overall wealth of that society, and more how evenly that wealth is distributed' (quoted in Stuart 2011: 12). Taking heed of the BMJ's statement in light of rising inequalities demands critique of the current economic model.

Moreover, the sort of economic growth many countries have pursued of late risks the sustainability of our planet. The Organisation for Economic Co-operation and Development (OECD) warns that 'a business-as-usual approach to growth and development would place grave pressures on the earth's biosphere... crossing [environmental thresholds] would entail real reduction in wellbeing and welfare' (OECD 2012: 41). Already we have exceeded three of nine planetary boundaries (Rockström et al. 2009) and 83 per cent of the world's people live in countries using more resources than their countries can renew (United Nations 2012: 47).

Yet the idea of infinite growth seems entrenched (albeit recently given a preface of 'sustainable', 'green' or 'inclusive'). While most people researching development or working as 'development practitioners' will point to its complex and wide-ranging elements, economic development as pursued by multinational organisations and governments around the world (with little exception) ostensibly hinges on an orthodox understanding of the economy which is increasingly discredited (see, for example, Jackson 2013: 25; and Johnson 2011: 17). Part of this orthodoxy is an inference that the success of a nation can be seen in the growth of its gross domestic product (despite GDP's creator, Simon Kuznets' warning otherwise). ${ }^{4}$ As the OECD admits, 'for a good proportion of the 20th century there was an implicit assumption that a growing GDP meant life must be getting better' (OECD 2008, Statistics, Policy and Knowledge 2007: Measuring and Fostering the Progress of Societies (back cover), quoted in Fioramonti 2013: 3).

But the environmental costs of growth are either unrecognised by GDP or even constitute an addition; the GDP paradigm inculcates a monetisation of human activity (as powerfully critiqued by Polanyi in 1944; and many studies point to a threshold of income beyond which there are few or no increases in wellbeing (see, for example, Michaelson et al. 2009). Again, this is recognised by the OECD: 'Increased income has come at the expense of increased inequality, longer working hours and greater complexity of our lives' (quoted in Fioramonti 2013: 3). Similarly Jackson (2013: 28) points to 'the declining quality of working time [from] pressure to create a continually growing economy'. Businesses treating employees as disposable factors of production (Trebeck 2011) is paralleled in short-termism which allows externalisation of 


\begin{tabular}{|c|c|c|}
\hline Latouche (cited in Fioramonti 2013: 133) & Victor (2008) & Marmot (Marmot et al. 2010) \\
\hline $\begin{array}{l}\text { Re-evaluate societal values to } \\
\text { elevate cooperation over } \\
\text { competition; altruism rather than } \\
\text { egoism; leisure instead of } \\
\text { obsession with work } \\
\text { Redefine poverty and wealth, } \\
\text { scarcity and abundance } \\
\text { Restructure productive apparatus } \\
\text { and recast social relations to } \\
\text { support new values } \\
\text { Redistribute resources using } \\
\text { ecological footprints as a } \\
\text { benchmark of equity } \\
\text { Relocalise production and } \\
\text { decision-making } \\
\text { Reduce the impact of consumption } \\
\text { and production } \\
\text { Reuse products } \\
\text { Recycle those products that } \\
\text { cannot be reused }\end{array}$ & $\begin{array}{l}\text { Stabilise consumption } \\
\text { Fewer status goods } \\
\text { Zero net investment with a shift } \\
\text { towards green and public goods } \\
\text { Balanced trade } \\
\text { Stabilise the population } \\
\text { Stabilise the capital stock and } \\
\text { change the composition } \\
\text { Stabilise and retrain the labour } \\
\text { force } \\
\text { Adopt more discriminating and } \\
\text { preventive technology } \\
\text { Reduce work time } \\
\text { Replace trickle-down poverty } \\
\text { reduction with redistribution and } \\
\text { in-kind support } \\
\text { Strengthen local economies } \\
\text { Education for life } \\
\text { Limit material and energy flows } \\
\text { Harvest renewable resources at } \\
\text { a rate which is below their } \\
\text { regeneration rate } \\
\text { Deplete non-renewable resources } \\
\text { at a rate that is slower than the } \\
\text { Preation of renewable substitutes } \\
\text { Eassimilative capacity } \\
\text { - carbon }\end{array}$ & $\begin{array}{l}\text { - Give every child the best start in life } \\
\text { maximise children and adults to } \\
\text { control over their lives } \\
\text { Create fair employment and good } \\
\text { work }{ }^{5} \text { for all } \\
\text { Create and develop healthy and } \\
\text { sustainable places and communities } \\
\text { Strengthen the role and impact of } \\
\text { ill health prevention }\end{array}$ \\
\hline
\end{tabular}

Items in bold represent themes explored in more depth in the following sections.

Source Author's own with data from Fioramonti (2013), Victor (2008) and Marmot et al. (2010).

environmental impact. Trucost shows the world's top industries would be unprofitable if their environmental costs were fully integrated into corporate bottom lines (cited in Roberts 2013): few companies or investors sufficiently pay for their pollution (Larkin 2013).

\section{A New Economic Paradigm}

'We are in need of a single, powerful concept to rival growth as development paradigm.'

Henk Molenaar

Influential economic scholars of the twentieth century have articulated the importance of narrative; a macro-vision. Keynes, for example, 'knew that policy advice, no matter how brilliantly argued, could be brushed aside so long as orthodox economic doctrines went unchallenged; to change the way the world thought about economic problems, he would have to invent a new paradigm' (cited in Polanyi Levitt 2013: 83). Friedman also pointed to the importance of an alternative set of ideas to replace dominant thinking: 'When the crisis occurs, the actions that are taken depend on the ideas that are lying around. That, I believe, is our basic function: to develop alternatives to existing policies, to keep them alive and available' (quoted in Miller and Hopkins 2013).

Building a new narrative entails 're-purposing' the economic system, shifting from the narrow confines of economic development (as discussed above, often distilled into incremental increases in GDP) towards broader, more humane and sustainable goals. With reference to sustainability, the World Bank highlights the pragmatism of such system change, as opposed to mitigation or amelioration alone: 'Downstream arrangements for dealing with risk are wasteful and often 


\section{Box 1 Building local economies}

A movement of local business is growing in the USA: the Business Alliance for Local Living Economies (BALLE). Its agenda is to 'rebuild the middle, engage in fair trade, and decentralize power and business ownership' (see BALLE n.d.). To advance this, BALLE connects and supports local business leaders; shares solutions, tools and strategies; and harnesses investment for the benefit of local economies. In 14 years BALLE's membership has grown to 50,000 businesses; 81 per cent of which operate in low-income and underserved communities. ${ }^{9}$

counter-productive' (quoted in Coote 2012: 11). Instead, Raskin et al. (2002: 62) point to the returns that flow from delivering substantive social justice and sustainability in the first place: a green dividend from cost-savings and ecoefficiency; a peace dividend from reduction in military expenditure; a human capital dividend from increased creativity and contribution of those currently consigned to poverty; a technological dividend from new opportunities from innovation; and a solidarity dividend from reduced security and police costs.

A tentative attempt to sketch the tenets of a new system (an NEP) that flows from a new purpose draws on three sources as laid out in Table 1 Serge Latouche's '8 Rs' of degrowth (cited in Fioramonti 2013); Peter Victor's (2008) model of a 'no growth' future for Canada to 2035; and Michael Marmot's work (2004: 112) on the social determinants of health (control, predictability, degree of support, threat to status, presence of outlets) which point to necessary changes in economic and social goals. Latouche is a leading 'degrowth thinker' and for some time has been articulating what an economy that does not perpetually grow entails. Victor - an environmental economist - has modelled how Canada would cope under various growth scenarios. His work can be seen as a theoretical 'proof of concept' and the assumptions he feeds into his models to ensure a benign outcome suggest some characteristics of an NEP. Marmot is an epidemiologist whose work illustrates the significance of the social determinants of health. Marmot may not immediately be an obvious source for exploration of an NEP, but his emphasis on prevention, the 'causes of the causes' of poor health, and his recognition of the importance of the wider circumstances in which people live their lives means his five points for change listed in Table 1 are useful in formulating a sketch of an NEP that can deliver health outcomes.

\section{What is the role of business in a New Economic Paradigm?}

'Instead of the goal of maximum linear growth in GDP, we should be thinking of maximum wellbeing for minimal planetary input.' Ian Cheshire

Since the 1980s shareholder value has become the ascendant mode of capitalism in Anglo-Saxon economies (Williamson, Driver and Kenway 2014). Yet pursuit of short-term ${ }^{6}$ shareholder value by many businesses (Davies 2009: 13) is seen by many as contributing to deleterious business impact on environmental and social justice outcomes. Kay, for example, warns of short-termist behaviour as 'modern public equity markets currently encourage exit (sale of shares) over voice' (cited in Hargreaves 2013).

Prioritisation of short-term shareholder value shapes incentive and reporting structures: in the United Kingdom and United States senior managers are paid mostly via bonuses and company equity (rather than basic salary), but 'the greater the bonuses, the greater the incentive for managers to favour actions that boost short-term profits at the expense of the longer-term future of the company and its shareholders (Smithers 2014: 78-9); see also Deakin (2014: 38) and Pryce (2014: 75).

Short-termism means decisions are made for the near future (Williamson et al. 2014: 10), rather than wider or longer-term environmental or social concerns. White (2006: 8) observes that such 'transience breeds carelessness towards future generations and drives the tendency to seek short-term gains at the expense of long-term stewardship of physical and human resources'. Chang (2010: 18) describes an 'unholy alliance between the professional managers and the shareholders... financed by squeezing the other stakeholders in the company'. At a societal level, Deakin (2014: 37) cites four cross-national studies which show that 'legal protections for 


\section{Box 2 Local energy provision}

In Denmark, Cumbers (2012) observed 'a diverse range of collectively owned institutions from state owned energy producers, local wind co-operatives which account for 80 per cent of the sector and municipally owned electricity distribution companies [which] ensure... public participation and engagement in economic decision-making'.

The Roundtable on Climate Change and Poverty in the UK heralds the potential of 'virtuous circles' which tackle climate change while delivering social benefits. They point to improving insulation in homes as a 'way to lower $\mathrm{CO}_{2}$ emissions and relieve the burden of fuel poverty... if the local workforce and local materials are used to make the necessary upgrades, local economic gains can be generated' (Johnson, Simms and Cochrane 2008: 9).

shareholder rights are correlated with... reduced innovation... higher earnings inequality... and a more uneven distribution of wealth'.

Moving away from the short-term and narrow objectives of certain businesses would enable more businesses to become delivery agents for many aspects of an NEP by paying more attention to the wider impacts of their operations and even seeking to deliver a greater set of goals. Here, only a small subset of potential activities is discussed: local economies, work and quality of output. They enable exploration of three key areas of change - respectively economic development that is built from the bottom up, as opposed to relying on 'trickle-down'; how work needs to be constructed, configured, and distributed in an NEP; and new ways of using resources that are less extractive and wasteful. These themes all feature in the changes identified by Latouche, Victor and Marmot in Table 1 (denoted in bold). Latouche, Victor and Marmot do not necessarily emphasise businesses as the key players in the evolution of an NEP - their ideas speak to a wider audience. The following discussion, however, illustrates that embracing the positive contribution businesses can make to an NEP positions business as an important ally in realising sustainable and just outcomes.

\subsection{Local economies}

'Production from local resources for local needs is the most rational way of economic life.' E.J. Schumacher

Strong local economies can be an antidote to extractive economies where communities are construed as merely clusters of customers and labour input. Local ownership supports a greater proportion of local income circulating locally (rather than leaking out), and then amplified by the local multiplier effect, and savings are channelled to local agendas (Robertson 1998: 142). US research (Fleming and Goetz 2011) points to a positive relationship between the proportion of locally owned firms and per capita income. ${ }^{7}$ For example, every US\$100 spent at locally owned businesses generates an additional US $\$ 58$ in local impact; compared to an additional US $\$ 33$ generated by a representative national chain store. ${ }^{8}$ Local businesses spend a larger percentage of revenue on labour (with potential to reverse declining wage shares) and are likely to have a sustained presence in the community rather than moving to ostensibly lower cost localities.

Locally focused economic development can also advance sustainability goals: lower emissions can be realised if more local needs are met using local resources. For example, decentralised energy (especially community-owned generation) can strengthen local economies, foster resilience to extreme weather and boost environmental awareness (Childs and McLaren 2012: 22), while retrofitting homes for energy efficiency can create reduced demand for energy and create employment for local residents.

Perhaps less obvious is the local dimension of the emerging field of collaborative consumption. ${ }^{10} \mathrm{It}$ is expected that sharing of expensive equipment will grow in the future (such as gardening or household tools or farm machinery) (Silver 2013). A strong local economy is often an enabling factor in a collaborative economy. For example, car and lift sharing initiatives are growing (Zipcar, City Car, Car Club, BlaBlaCar and so on). ${ }^{11}$ There is a potential environmental benefit from such schemes: the World Wildlife Fund (WWF) estimates that every shared car takes 14 cars off the road (WWF quoted in Slavin 2012). But car 


\section{Box 3 Cooperatives in the UK}

The number of cooperatives in the UK is growing: between 2008 and 2011 the sector grew by over 25 per cent to more than 6,000 (see Co-operatives UK 2014). They are owned by 15 million people (more than the number of people who own shares directly) and contribute over $£ 37$ billion to the UK economy (ibid.).

Green City is a food wholesaler formed as a workers' cooperative in 1978 (see case study written up in more depth in Whittam and Talbot 2014). Located in Glasgow's East End, its website describes a vision of creating 'a non-exploitative workplace which takes into consideration the interests of the workers, the community and the environment as a whole' (Green City Wholefoods n.d.). It employs 35 people -30 of whom are members. ${ }^{15}$ All members are involved in decision-making: 'Each individual has a certain level of autonomy... [and] are organised into teams [which]... make decisions about their own area'. A fifth of its $£ 4.7$ million ${ }^{16}$ turnover is spent in Glasgow; approximately the same proportion of suppliers are 'local' ${ }^{17}$ and all but one staff member lives in Glasgow. Green City has a policy of recruiting locally and using local services and actively supports the local community (sponsoring a local school football team and undertaking school visits).

sharing depends on local context - safe spaces to park cars, a critical mass of potential customers living nearby who - crucially - can afford car rental. Since collaborative consumption is often held up as one mechanism to reduce environmental impact (and cultivate community relations), robust local economies emerge as not just a goal in their own right, but an important enabling context for other aspects of an NEP. ${ }^{12}$

\subsection{Work}

'So long as we have one person seeking work who cannot find it, the hours of work are too long'.

American labour leader Samuel Gompers (1887)

Literature on the social determinants of health (including self-determination theory) ${ }^{13}$ reveals that the nature of work - not just its quantity and pay - shapes people's ability to live good lives. ${ }^{14}$ The extent to which workers participate in the direction of their work; derive a sense of meaning from it; and are connected to other workers determines their sense of coherence and control, which in turn affects mental and physical health. For example, the 2010 Marmot Review (Marmot et al. 2010) warned that insecure and poor-quality employment is... associated with increased risks of poor physical and mental health'. Butterworth et al. (2011) found that moving from unemployment to a lowquality job results in a decline in mental health. Similarly, Becker and Paulusma (2011) found that poorer mental health outcomes are linked to precarious employment. Not only is mental health affected: the World Health Organization (WHO) identifies stress at work as associated with 50 per cent excess risk of heart disease and a range of physical health risks (cited in Davies 2009: 53). But the benefits of quality work go beyond the individual: remuneration with which to participate in society; taxes paid by workers as earners and as consumers; and reduced need for out-of-work benefits (and reduced disability benefits if people avoid ill health via positive workplace experiences).

One mechanism to inculcate decent work is via 'pro-social businesses': organisations managed in a way that provides for greater worker autonomy; participation in decisions; and facilitates relationships with colleagues. Cooperatives are an example - they have been in existence since the eighteenth century (pre-dating modern corporations by 100 years). Cooperatives measure their performance not by profit, but by the flow of benefits to members and present a mechanism to share wealth (to employee or community owners). For example, employeeowned businesses enable a more even distribution of total worker compensation, with higher pay and benefits relative to their counterparts in non-employee-owned firms (see evidence cited in Whittam and Talbot 2014). Democracy and participation are inherent in cooperatives. It has been found (Davies 2009: 93) that employee-owned firms generate happier, healthier employees and surrounding communities. Whittam and Talbot cite findings 


\section{Box 4 Alternative fulfilment for environmental and wellbeing benefits}

Antonovsky points to meaningfulness as key to health and wellbeing (cited in Walsh et al. 2013: 42). Skidelsky (2013: 23) identifies health, security, respect or dignity, friendship, harmony with nature and leisure as important for a good life. Other evidence (see, for example, Pretty et al. 2015 and Gleibs 2013) shows people are happiest not when consuming, but when they spend time socialising, in nature and learning. For example, volunteering brings improved happiness, self-esteem, sense of control and better mental health (see Pretty et al. 2015); while 80 per cent of British people say that sharing makes them happier (Simms and Potts 2012: 17). This points to non-consumption-orientated activities as a means to fulfilment.

Non-consumption-orientated activities also have potential to support sustainability objectives. Kasser (cited in Pretty 2013) identifies low-carbon-intensive activities such as going for a walk, reading a book, voluntary work, meditation, playing with your children, dancing or painting. Similarly, fishing, gardening and bird-watching are low carbon (unless fossil-fuel transport is needed) (Pretty 2013).

of a positive effect of employee engagement on physical, emotional and financial health, and wellbeing (Macleod and Clarke 2009; and Kular et al. 2008, cited in Whittam and Talbot 2014).

Sharing the benefits of (good) work more evenly requires a better distribution of work itself: ${ }^{18}$ more hours for those who have too few and reduced hours for those working too many. Mechanisms include early retirement; increased vacation time; school term shifts; extended care leave; sabbaticals; more part-time working; job sharing; and parental leave. This has potential to reduce 'ill-being' from unemployment and, for others, excessive work hours (Coote, Franklin and Simms 2010: 3; Simms 2013). Shorter working weeks could encourage slower and more sustainable ways of living and allow more time for caring activities. Schor (2011: 7) has found that with less time at work people can fortify social networks. In terms of personal consumption patterns, shorter working hours might release time for sustainable lifestyles: purchasing falls with a shorter working week and lower income; and there is lowering resource use and lowering use of resource-heavy items. ${ }^{19}$

A hint of what this looks like is evident in a response to the recent recession: in many OECD countries governments (admittedly temporarily) subsidised short-time working so firms could adjust hours to preserve jobs (Silim 2013: 5). Pre-dating the recession, the Netherlands emerges as an exemplar with some of the lowest working hours. ${ }^{20}$ Strong rights to reduce working hours and take career breaks, and with incentives to do so, make working less the norm in the Netherlands.

\subsection{Quality (rather than quantity) of output}

'[We need an] economics of maintenance, qualitative improvements, sharing, frugality, and adaptation to natural limits. It is an economy of better not bigger.'

Herman Daly

An NEP entails more of what is good for us, and less of what harms people and the planet. Nearly two thirds of people believe that as a society we need to consume a lot less to improve the environment for future generations (Globescan 2012). There is a wider context behind people's consumption, but space precludes addressing that here, beyond noting that inequality feeds status anxiety that in turn drives people to certain types of consumption (see for example, Carlisle, Hanlon and Hannah 2008; and Hamilton 2011). Structural drivers of consumption aside, achieving lower and new modes of consumption requires changing how products are used: cherishing/repairing more and focusing on experiences rather than ownership. This would entail cultivating non-material dimensions of fulfilment (Raskin et al. 2002: 42) via increased consumption of services and improvement in quality rather than quantity of consumption (Rosnick 2013).

Emphasising quality also entails dematerialisation (consumption decoupled from throughput) (Raskin et al. 2002: 47). Simms and Potts (2012: 10, 24) propose a 'new materialism' which requires high labour input via reuse, recycling, and 


\section{Box 5 Circular business}

A trend with potential to reduce deleterious environmental impacts is the circular economy (Vaughn 2014). A circular economy keeps resources in the economy longer and so minimises energy, water, land use and waste disposal. Via direct reuse and re-manufacturing it 'restores old products, parts and materials back to their original use in a way that uses the least resources to deliver the same functioning' (Benton and Hazell 2013: 4, 15).

A circular economy will require new business models (if not new businesses). For example, instead of selling items, people are sold use (temporary ownership) of an item - or even the outcome of an action. This might entail people leasing a high-value machine or tool, rather than purchasing a low-quality one. The 'business case' for this shift was laid out by B\&Q's then CEO (Cheshire 2011): 'We are now faced with the need for real reinvention of our high resource-impact business models... Business models assuming an implicit abundance of free resources cannot by definition be sustainable.'

re-purposing (underpinned by strong local economies as discussed previously). If businesses can embrace circular economy principles such dematerialisation might be possible.

\section{Getting there}

These developments challenge predominant ways of doing business. Profound changes are required to take them from still marginal examples, including, as briefly illustrated next: new drivers of business behaviour; widened goals for the business themselves; and new business configurations.

\subsection{Incentives driving business}

Formal and informal incentives encourage businesses to align their activities with an NEP. These include taxation, how businesses measure and assess their performance, and the context in which businesses operate and employees live:

Taxation: ${ }^{21}$ levers provided in the tax system include using tax to charge for use of the commons and so costs currently externalised become internal considerations; shifting the tax base from income and number of workers to hours (OECD 2012: 19); and taxes on overtime $^{22}$ (one of Hollande's first acts as French president was to re-introduce taxation of overtime in excess of 35 hours (Hayden 2013: 128)). The reverse of taxation is subsidies which can support, for example, design of products which allow reuse and repair or financial support for renewable energy infrastructure.

- Measurement: scrutiny of non-financial results can focus attention on a range of impacts and facilitate accountability to a broader set of audiences. Already steps in this direction are evident: in May 2011 Puma published the first attempt to measure, value and report environmental externalities in its entire supply chain..$^{23}$ As at 2012, 86 companies had agreed to draw up natural capital accounting rules. Measuring beyond the bottom line is becoming formalised; for example, mechanisms such as the International Organisation for Standardisation (ISO) developed standards which guide firms seeking to reduce pollution and protect the environment (ISO 14001) and ISO26000 offers guidance for corporate social responsibility (CSR).

- Context: making non-work and nonconsumption activities appealing and accessible for employees requires a conducive setting such as safe spaces; affordable public transport; and attractive community spaces in which to undertake non-consumptionorientated activities. Tools the state could use to cultivate this context include planning and zoning, and public procurement (for example, to support locally owned businesses offering affordable activities and experiences as an alternative to consumption) (Rodriguez and Houston 2007). In terms of informing people's consumption choices towards quality rather than quantity, government already uses a range of tools to highlight the environmental impact of purchases: energy efficiency standards; $\mathrm{CO}_{2}$ labels; and education (OECD 2012: 18, 22). Making businesses responsible for ultimate disposal of their products would be a step beyond this. Some Japanese 
manufacturers, for example, are legally responsible for end-of-life disposal which results in better design for disassembly. ${ }^{24}$

\subsection{Widened business goals and motivations}

Incentives constitute the external push and pull factors; goals are the internal equivalent. For businesses to fulsomely contribute to an NEP, their purpose needs to encompass positive social and ecological outcomes. Hargreaves (2013) calls for company law to be re-written to rank employees, customers and society alongside shareholders as beneficiaries of the corporation. Company boards could also include a range of constituencies. Such arrangements are already in existence: in France, Germany and Japan, for example, businesses have a diversity of stakeholders to whom they owe a responsibility (Crouch 2011: 103).

Such changes broaden corporate considerations by internalising costs currently seen as externalities (or irrelevant to business) and encouraging delivery of 'positive externalities'. Legislation is already shifting in this direction. For example, public interest companies in the UK combine features of profit seeking and notfor-profit (dividends to shareholders cannot exceed 35 per cent of profit and they must demonstrate community or public interest). The UK Companies Act 2006 stipulates duties of company directors to include regard for and reporting on the company's impacts on communities and environment. Germany has the Gemeinnutzige (public interest limited company) and the USA has Benefit Corporations (a formal extension of the purpose of a corporation towards generating impact or benefits for society).

\subsection{Reconstituting business}

New configurations of business which further subordinate pursuit of profit relative to other goals go a step further than more demanding incentives or wider goals: different businesses themselves, configured to deliver aspects of an NEP (as opposed to an add-on or by-product) (Clinton 2013; Davies 2009: 14). Cooperatives have been discussed above, but Gar Alperovitz (2013) calls for a 'pluralist commonwealth' comprising cooperatives alongside neighbourhood corporations, municipal enterprises, new ways of banking and investing, regional energy, land trusts, national public firms and participatory budgeting. According to Maclurcan and Hinton (forthcoming) the growth in number of not-forprofit businesses (in the US faster growth than the for-profit sector between 2001 and 2011) constitutes a way to enhance 'real community wealth' and create a more equitable economy in which not-for-profit businesses are required - by law - to reinvest, rather than privatise, profits.

In terms of raising the proportion of businesses that are 'pro-social', education (particularly what would-be business-people are taught about suitable business models); financial support; procurement; and tax incentives are important. For example, recently the UK passed the Finance Bill which incorporates a provision to give capital gains tax relief following 'a qualifying disposal of shares to an employee ownership trust [namely a controlling stake] and income tax relief for bonuses paid to employees of employee-controlled businesses' (see HM Revenue and Gustoms n.d.; and UK Government 2014). Such steps will spur advisers (accountants and lawyers) to bring the option of an employee buy-out to the attention of people selling their business (Davies 2009: 95). Some regulators are almost mandating some degree of ownership sharing: in France profit-sharing is a statutory obligation on all companies with more than 50 employees.

But utilising businesses to achieve the goals of an NEP also requires that people pursuing social and environmental objectives see business as a mechanism to deliver such goals.

\section{Conclusion - implications for international development}

The sort of growth cultivated in the last few decades has come without sufficient regard to its quality or distribution. In business this was manifest in excessive focus on shareholder value and short-term objectives, which undermine social justice and sustainability. Instead, by (inter alia) reconstituting businesses, imbuing them with widened goals, and concertedly incentivising NEP behaviours, the contribution of business to an NEP can be galvanised in areas such as local economies, decent work and quality (rather than quantity) of output.

Yet, a countervailing force will be the strength of vested interests, those who (appear to) benefit from preservation of the GDP-orientated mode 
of development. That some businesses are already appreciating the necessity of an NEP will go some way to countering this resistance. Such recognition amongst businesses is often due to, inter alia, appreciation of resource constraints; a result of collaboration with (or following antagonism from) aspects of civil society; the lure of tax incentives; or compulsion of legislation. It seems unusual coalitions of enlightened 'NEP businesses' (as exemplars) and civil society organisations will be needed to advocate for the necessary legislative architecture and to support laggards to learn from and emulate enterprises supporting various aspects of an NEP.

\section{Notes}

* Dr Trebeck is writing in a solely personal capacity.

1 The term 'Build Back Better' derives from humanitarian response contexts and, inspired by this usage, was utilised in relation to the economy by the author in a $2014 \mathrm{blog}$ (Trebeck 2014).

2 These are more than adequately presented in Polanyi Levitt (2013); International Bank for Reconstruction and Development and World Bank (2012); and Stuart (2011).

3 This discussion talks about 'business' in a way that implies large corporations, but it does so not to ignore the reality that small and medium enterprises employ more people and, numerically, make up a larger proportion of the private sector. The focus on larger businesses reflects the political and economic power these enterprises yield which can result in changes and processes which undermine developmental goals (see, for example, Malleson 2014).

4 Simon Kuznets said in 1962 that 'the welfare of a nation can scarcely be inferred from a measurement of national income as defined [by Gross Domestic Product]'.

5 See, for example, Deci and Ryan (2008) and Warhurst and Trebeck (2013).

6 The extent of short-termism was revealed in a recent report for the UK Government Office for Science: by '2008 in all the main OECD stock exchanges the average holding period was less than a year and in the case of the USA had fallen from 5 years in the 1980s to around 5 months by 2011' (Hughes 2013).

7 But this holds only for small firms (under 100 employees); areas with a high density of large, non-locally owned firms have a negative effect.
Finally, an NEP is about upstream change via systemic shifts. An NEP will deliver social and environmental outcomes in the first place rather than simply ameliorating or mitigating damage of current systems. As such it goes beyond any development agendas and practices which are disconnected from the wider political and economic context and transcends any projects prioritising numeric quantification of short-term 'impact'. There was not space to explore this in depth here, but more consideration and research is required to appreciate and link the goals (let alone necessity) of an NEP with long-term development funding, collaboration, and advocacy for justice rather than amelioration.

8 So locally owned businesses contribute 76 per cent greater return to the local economy compared to money spent at national chains (Patel and Martin 2011). The standardised contribution of resident-owned firms is more than four times that of large non-residentowned firms (Fleming and Goetz 2011).

9 Email communication with Michelle Long, executive director, BALLE and author, October 2014.

10 The terms 'sharing economy'; 'peer-to-peer economy'; 'collaborative economy' and 'collaborative consumption' are often used interchangeably. The term collaborative consumption is preferred here because it allows commercial transactions (for example, several people renting the same item from a retailer at different points in time). A key characteristic is a range of users of one item and it offers a mechanism to 'sweat' underutilised assets (Thomas 2012).

11 Even Hertz has launched a short-term car rental system called Hertz 24/7.

12 In turn, a strong local economy in which sharing is common feeds into wellbeing benefits: 80 per cent of British people say that sharing makes them happier (Simms and Potts 2012: 17).

13 Namely Deci and Ryan's exploration of motivation and goals which lead to high wellbeing; they identified autonomy, competence, relatedness as three basic psychological needs which result in wellbeing (Deci and Ryan 2008).

14 See Warhurst and Trebeck (2013) for a fuller exploration of what decent work entails.

15 The others are either on temporary contracts or undertaking a probationary period. 
16 Exclusive of VAT.

17 Located within 50 miles of Glasgow.

18 Of course any step to distribute work in a more balanced way must be cognisant of the risk that some low-paid workers will be worse off and take steps to address this through Living Wages and social protection. Housing must also be affordable - in many cities expensive housing compels people to work long hours to afford rent or mortgages.

19 An obvious example being drying washing on the line rather than using a tumble dryer (Schor 2011: 114). Higher national footprint associated with higher average hours per person, controlling for income, GDP, productivity and other variables (Hayden and Shandra cited in Schor 2013: 11).

201,377 a year per person compared to 1,778 in the USA and 1,647 in the UK; and one in three men work part-time or compressed hours (Dietz and O'Neill 2013: 135).

21 Some might argue that this creates perverse incentives - space does not allow discussion here, but that concern needs to be acknowledged.

\section{References}

Alperovitz, G. (2013) What Then Must We Do? Straight Talk About the Next American Revolution, White River Junction VT: Green Press Initiative BALLE (Business Alliance for Local Living Economies) (n.d.) Why We do This Work, https://bealocalist.org/Why_we_work (accessed 1 January 2015)

Beck, U. (2013) 'Why "Class" is Too Soft a Category to Capture the Explosiveness of Social Inequality at the Beginning of the Twenty-First Century', British Journal of Sociology 46.1: 63-74

Becker, F. and Paulusma, P. (2011) 'Hidden

Depression in the Workplace', in

M. McTernan (ed.), Social Progress in the 21st Century: Social Investment, Labour Market Reform and Intergenerational Inequality, London: Policy Network,Wiardi Beckman Stichting, Foundation for Progressive European Studies, www.policy-network.net/publications/4027/ Social-progress-in-the-21st-Century (accessed 12 October 2011)

Benton, D. and Hazell, J. (2013) Resource Resilient UK - A Report from the Circular Economy Task Force, London: Green Alliance

Butterworth, P.; Leach, L.S.; Strazdins, L.; Olesen, S.C.; Rodgers, B. and Broom, D.H.
22 Pullinger suggests higher taxes on long working hours and overtime, and provides benefits and tax credits for shorter hours and career breaks (and points out that this could be fiscally neutral) (Pullinger 2013: 97). See also Coote et al. (2010: 29).

23 Reportedly, 72 per cent of Puma's profits would go if they had to pay for environmental impact.

24 In Japan 74-89 per cent of materials and components are recovered in new products, compared to 30-40 per cent in the UK (Benton and Hazell 2013: 19).

25 The full list of contributors to this article is: Rockström, J.; Steffen, W.; Noone, K.; Persson, A.; Chapin, S.; Lambin, E.; Lenton, T.; Scheffer, M.; Folke, C.; Schellnhuber, H. J.; Nykvist, B.; de Wit, C.; Hughes, T.; van der Leeuw, S.; Rodhe, H.; Sörlin, S.; Snyder, P.; Costanza, R.; Svedin, U.; Falkenmark, M.; Karlberg, L.; Corell, R.; Fabry, V.; Hansen, J.; Walker, B.; Liverman, D.; Richardson, K.; Crutzen, P. and Foley, J.

(2011) 'The Psychosocial Quality of Work Determines Whether Employment has Benefits for Mental Health', Occupational Environmental Medicine 68.11: 806-12, www.medscape.com/viewarticle/751400 (accessed 31 October 2014)

Carlisle, S.; Hanlon, P. and Hannah, M. (2008) 'Status, Taste and Distinction in Consumer Culture: Acknowledging the Symbolic Dimensions of Inequality', Public Health 122.6: 631-7, http://eprints.gla.ac.uk/4140/ (accessed 31 October 2014)

Chang, H.-J. (2010) 23 Things They Don't Tell You About Capitalism, London: Allen Lane

Cheshire, I. (2011) 'Imagining a New, Sustainable Capitalism', The Guardian, 24 March, www.theguardian.com/sustainablebusiness/blog/kingfisher-ceo-ian-cheshiresustainable-capitalism (accessed 21 May 2013)

Childs, M. and McLaren, D. (2012) Mapping a Route from a Planet in Peril to a World of Wellbeing, London: Friends of the Earth

Clinton, L. (2013) 'How Firms Innovate their Business Models for Sustainability', SustainAbility Blog, 16 September, www.sustainability.com/blog/how-firmsinnovate-their-business-models-forsustainability (accessed 1 October 2014) 
Co-operatives UK (2014) The Co-operative Economy 2014, www.uk.coop/co-operative-economy-2014 (accessed 1 January 2015)

Coote, A. (2012) The Wisdom of Prevention: Long-term Planning, Upstream Investment and Early Action to Prevent Harm, London: New Economics Foundation, www.neweconomics.org/ publications/entry/the-wisdom-of-prevention (accessed 18 August 2014)

Coote, A.; Franklin, J. and Simms, A. (2010) 21 Hours: Why a Shorter Working Week Can Help Us All to Flourish in the 21st Century, London: New Economics Foundation

Crouch, C. (2011) The Strange Non-death of Neoliberalism, Cambridge: Polity Press

Cumbers, A. (2012) Reclaiming Public Ownership: Making Space for Economic Democracy, London: Zed Books

Davies, W. (2009) Reinventing the Firm, London: Demos, www.demos.co.uk/publications/ reinventing-the-firm (accessed 23 December 2009)

Deakin, S. (2014) 'Against Shareholder

Empowerment', in J.Williamson, C. Driver and P. Kenway (eds), Beyond Shareholder Value: The Reasons and Choices for Corporate Governance Reform, London: Trades Union Congress, New Policy Institute, SOAS, www.tuc.org.uk/sites/default/ files/BSV.pdf (accessed 23 December 2014)

Deci, E. and Ryan, R. (2008) 'Self-determination Theory: A Macrotheory of Human Motivation, Development, and Health', Canadian Psychology 49.3: $182-5$

Dietz, R. and O’Neill, D. (2013) Enough is Enough: Building a Sustainable Economy in a World of Finite Resources, Routledge: Abingdon

Fioramonti, L. (2013) Gross Domestic Problem, London: Zed Books

Fleming, A. and Goetz, S.J. (2011) 'Does Local Firm Ownership Matter?', Economic Development Quarterly 25.3: 277-81

Fuentes-Nieva, R. and Galasso, N. (2014) 'Working for the Few: Political Capture and Economic Inequality', Oxfam Briefing Paper 178, Oxford: Oxfam International, www.oxfam.org/ en/policy/working-for-the-few-economicinequality (accessed 15 July 2014)

Gleibs, I. (2013) 'Does Money Buy Happiness? It Depends on the Context', LSE Blog, 3 July, http://blogs.lse.ac.uk/politicsandpolicy/doesmoney-by-happiness-a-dynamic-analysis-ofrelationships-between-financial-and-socialcapital-on-life-satisfaction/ (accessed 5 August 2013)
Globescan (2012) Re-thinking Consumption: Consumers and the Future of Sustainability, London: BBMG, Globescan and SustainAbility, www.globescan.com/component/edocman/ ?view $=$ document $\&$ id $=46 \&$ Itemid $=591$ (accessed 31 October 2012)

Green City Wholefoods (n.d.) www.greencity.coop (accessed 1 January 2015)

Hamilton, K. (2011) Keeping Up Appearances, Consumption and Masking Poverty?, Whose Economy Seminar Paper, Oxford: Oxfam GB and University of the West of Scotland, http://policy-practice.oxfam.org.uk/ publications/keeping-up-appearancesconsumption-and-masking-poverty-146575 (accessed 30 January 2012)

Hargreaves, D. (2013) 'Does the Shareholder Owned Company Have a Future?', High Pay Centre Blog, 8 July, http://highpaycentre.org/ blog/does-the-shareholder-owned-companyhave-a-future (accessed 22 July 2014)

Hayden, A. (2013) 'Patterns and Purpose of Work-Time Reduction - A Cross-National Comparison', in A. Coote and J. Franklin (eds), Time on Our Side: Why We All Need a Shorter Working Week, London: New Economics Foundation

Hillier, D. and Castillo, G. (2013) 'No Accident: Resilience and the Inequality of Risk', Oxfam Briefing Paper 172, Oxford: Oxfam International

HM Revenue and Customs (n.d.) Tax Incentives for Employee Ownership Trusts, www.gov.uk/ government/uploads/system/uploads/ attachment_data/file/264598/7._Employee _ownership.pdf (accessed 1 January 2015)

Hughes, A. (2013) Short-termism, Impatient Capital and Finance for Manufacturing Innovation in the UK, Future of Manufacturing Project, Evidence Paper 16, London: Foresight, Government Office for Science, www.gov.uk/government/ uploads/system/uploads/attachment_data/file/ 283883/ep16-manufacturing-short-termismcapital-finance.pdf (accessed 23 December 2014)

International Bank for Reconstruction and Development and World Bank (2012) Inclusive Green Growth - The Pathway to Sustainable Development, Washington DC: World Bank, http://siteresources.worldbank.org/EXTSDNET/ Resources/Inclusive_Green_Growth_May_ 2012.pdf (accessed 20 August 2014)

Jackson, T. (2013) 'The Trouble with Productivity', in A. Coote and J. Franklin (eds), Time on Our 
Side: Why We All Need a Shorter Working Week, London: New Economics Foundation

Johnson, I. (2011) Sustainability Under Scrutiny: Real Values and their Role in Promoting the New Economics of Growth, The Club of Rome

Discussion Paper 01/11, Winterthur: Club of Rome

Johnson, V.; Simms, A. and Cochrane, C. (2008) Tackling Climate Change, Reducing Poverty: The First Report of the Roundtable on Climate Change and Poverty in the UK, London: New Economics Foundation, www.foe.co.uk/sites/default/files/ downloads/tackling_climate_change_re.pdf (accessed 23 December 2014)

Larkin, A. (2013) 'Why Companies Need to be Held to Account Over their Environmental Debt', The Guardian, 10 July

Macleod, D. and Clarke, N. (2009) Engaging for Success: Enhancing Performance Through Employee Engagement, London: Office of Public Sector Information

Maclurcan, D. and Hinton, J. (forthcoming) 'How on Earth: Flourishing in a Not-For-Profit World by 2050', White River Junction VT: Chelsea Green Publishing

Malleson, T. (2014) After Occupy, New York NY: Oxford University Press

Marmot, M. (2004) The Status Syndrome - How Social Standing Affects Our Health and Longevity, New York NY: Holt Paperbacks

Marmot, M.; Atkinson, T.; Bell, J.; Black, C.; Broadfoot, P.; Cumberlege, J.; Diamond, I.; Gilmore, I.; Ham, C.; Meacher, M. and Mulgan, G. (2010) Fair Society, Healthy Lives: Strategic Review of Health Inequalities in England post-2010, The Marmot Review, London: University College London, www.instituteofhealthequity.org/projects/fairsociety-healthy-lives-the-marmot-review (accessed 1 February 2012)

Michaelson, J.; Abdallah, S.; Steuer, N.; Thompson, S. and Marcs, N. (2009) National Accounts of Well-being: Bringing Real Wealth onto the Balance Sheet, London: New Economics Foundation, www.nationalaccountsof wellbeing.org/learn/download-report.html (accessed 16 February 2010)

Miller, A. and Hopkins, R. (2013) Climate After Growth: Why Environmentalists Must Embrace Postgrowth Economics and Community Resilience, Santa Rosa: Post Carbon Institute and Transition Network, www.resilience.org/stories/ 2013-09-30/climate-after-growth-whyenvironmentalists-must-embrace-post-growth- economics-community-resilience (accessed 31 October 2014)

Nadal, A. (2012) Rio +20: A Gitizen's Background Document, Mexico Gity: Center for Economic Studies, El Colegio de Mexico, www.google.co.uk/url?q=http://eco-labs.org/ index.php/papers/doc_download/37-rio20-acitizens-background-document \&sa $=\mathrm{U} \& \mathrm{ei}=$ fh54UO-THuTY0QX43IHQBw\&ved = 0CBUQFjAA\&usg=AFQjCNG_p2PjlOQIjDxm D-hcXIO7wD_Irg (accessed 11 October 2012) OECD (2012) Inclusive Green Growth: For the Future We Want, Paris: OECD, www.oecd.org/ greengrowth/Rio + 20\%20brochure\%20FINAL \%20ENGLISH\%20web\%202.pdf (accessed 31 October 2014)

Patel, A. and Martin, G. (2011) Going Local: Quantifying the Economic Impacts of Buying from Locally Owned Businesses in Portland, Maine, Augusta MA: Maine Center for Economic Policy Pennycook, M. and Whittaker, M. (2012) Low Pay Britain, London: Resolution Foundation, www.resolutionfoundation.org/publications/ low-pay-britain-2012/ (accessed 22 July 2014)

Polanyi, K. (1944) The Great Transformation: The Political and Economic Origins of Our Time, 2001, 2nd ed., Boston MA: Beacon Press

Polanyi Levitt, K. (2013) From the Great Transformation to the Great Financialisation: On Karl Polanyi and Other Essays, Black Point: Fernwood Publishing

Pretty, J. (2013) 'The Consumption of a Finite Planet: Well-being, Convergence, Divergence and the Nascent Green Economy', Environmental and Resource Economics 55.4: 475-99

Pretty, J.; Barton, J.; Bharucha, Z.; Bragg, R.; Pencheon, D.; Wood, C. and Depledge, M.H. (2015) 'Improving Health and Well-being Independently of GDP: Dividends of Greener and Prosocial Economies', International Journal of Environmental Health Research 11: 1-26, www.ncbi.nlm.nih.gov/pubmed/25670173 (accessed 5 May 2015)

Pryce, V. (2014) 'Is Corporate Governance What is Wrong with our Economy?', in

J. Williamson, C. Driver and P. Kenway (eds), Beyond Shareholder Value: The Reasons and Choices for Corporate Governance Reform, London: Trades Union Congress, New Policy Institute, SOAS, www.tuc.org.uk/sites/default/files/BSV.pdf (accessed 23 December 2014)

Pullinger, M. (2013) 'The "Green Life Course" Approach to Designing Working Time Policy', in A. Coote and J. Franklin (eds), Time on Our 
Side: Why We All Need a Shorter Working Week, London: New Economics Foundation

Raskin, P.; Banuri, T.; Gallopin, G.; Gutman, P.; Hammond, A.; Kates, R. and Swart, R. (2002) The Great Transition: The Promise and Lure of the Times Ahead, Boston MA: Global Scenario Group

Resolution Foundation (2012) Gaining from Growth: The Final Report of the Commission on Living Standards, London: Resolution Foundation, www.resolutionfoundation.org/publications/ gaining-growth-final-report-commissionliving-standards (accessed 22 July 2014)

Roberts, D. (2013) World's Top Industries Shown to be Unprofitable..., Green Economy Coalition, www.greeneconomycoalition.org/know-how/ world (accessed 14 June 2013)

Robertson, J. (1998) Beyond the Dependency Culture - People, Power and Responsibility, Twickenham: Adamantine Press

Rockström, J. et al..$^{25}$ (2009) 'Planetary Boundaries: Exploring the Safe Operating Space for Humanity', Ecology and Society 14.2: 32, www.ecologyandsociety.org/vol14/iss2/art32/ (accessed 31 October 2014)

Rodriguez, H. and Houston, D. (2007) Procurement Matters: The Economic Impact of Local Suppliers, Austin TX: Civic Economics, http://bealocalist.org/ sites/default/files/file/ Local\%20First\%20studies/procurementmatters.pdf (accessed 22 July 2014)

Rosnick, D. (2013) Reduced Work Hours as a Means of Slowing Climate Change, Washington DC: Center for Economic and Policy Research, www.cepr.net/documents/publications/climatechange-workshare-2013-02.pdf (accessed 22 July 2014)

Schor, J. (2013) 'The Triple Dividend', in A. Coote and J. Franklin (eds), Time on Our Side: Why We All Need a Shorter Working Week, London: New Economics Foundation

Schor, J. (2011) True Wealth: How and Why Millions of Americans are Creating a Time-rich, Ecologically Light, Small-scale, High Satisfaction Economy, New York NY: Penguin

Schwartz, J. (2010) 'Is GDP an Obsolete Measure of Progress?', Time, 30 January, www.time.com/time/printout/0,8816,1957746, 00.html (accessed 19 August 2013)

Silim, A. (2013) Job Creation: Lessons from Abroad, London: Trades Union Congress

Silver, J. (2013) 'The Sharing Economy: A Whole New Way of Living', The Observer, 4 August Simms, A. (2013) 'The Four-day Week: Less is More', The Guardian, 22 February, www.guardian.co.uk/money/2013/feb/22/fourday-week-less-is-more (accessed 21 May 2013)

Simms, A. and Potts, R. (2012) The New

Materialism - How Our Relationship with the Material World Can Change for the Better, London: Bread, Print, Roses, www.thenewmaterialism.org/pamphlet (accessed 22 August 2014)

Skidelsky, R. (2013) 'In Search of the "Good Life", in A.Coote and J. Franklin (eds), Time on Our Side: Why We All Need a Shorter Working Week, London: New Economics Foundation Slavin, T. (2012) 'Time to Turn Capitalism "Inside Out" - Roundtable Report', The Guardian, 5 December, www.guardian.co.uk/sustainablebusiness/sustainability-roundtable-interface (accessed 5 May 2013)

Smithers, A. (2014) 'The Change in Management Behaviour', in J. Williamson, C. Driver and P. Kenway (eds), Beyond Shareholder Value: The Reasons and Choices for Corporate Governance Reform, London: Trades Union Congress, New Policy Institute, SOAS, www.tuc.org.uk/sites/default/files/BSV.pdf (accessed 23 December 2014)

Stuart, E. (2011) Making Growth Inclusive - Some Lessons from Countries and the Literature, Oxfam Research Reports, Oxford: Oxfam International

Thomas, S. (2012) 'The Great Recovery', RSA Blog, www.thersa.org/fellowship/journal/archive.... (accessed 25 July 2013)

Trebeck, K. (2014) 'Build Back Better: Time for a New Economic Model', Oxfam Policy and Practice Blog, 1 April, http://policypractice.oxfam.org.uk/blog/2014/04/buildback-better-time-for-a-new-economic-model (accessed 1 January 2014)

Trebeck, K. (2011) Whose Economy? The Winners and Losers in the New Scottish Economy, Oxfam: Oxford: http://policy-practice.oxfam.org.uk/ publications/whose-economy-winners-andlosers-in-the-new-scottish-economy-118965 (accessed 29 August 2011)

UK Government (2014) Finance Act 2014, London: TSO, www.legislation.gov.uk/ukpga/ 2014/26/pdfs/ukpga_20140026_en.pdf (accessed 1 January 2015)

United Nations (2012) Defining a New Economic Paradigm: The Report of the High Level Meeting on Wellbeing and Happiness, New York NY: United Nations, www.uncsd2012.org/content/ documents/519BhutanReport_WEB_F.pdf (accessed 19 October 2012) 
Vaughn, J. (2014) The Circular Economy, New York NY: JWT Intelligence, www.jwtintelligence.com/ wp-content/uploads/2014/06/F_JWT_TheCircular-Economy.06.20.14.pdf (accessed 23 December 2014)

Victor, P. (2008) Managing Without Growth: Slower by Design, Not Disaster, Northampton: Edward Elgar

Walsh, D.; McCartney, G.; McCullough, S.; van der Pol, M.; Buchanan, D. and Jones, R. (2013) Exploring Potential Reasons for Glasgow's 'Excess' Mortality: Results of a Three-City Survey of Glasgow, Liverpool and Manchester, Glasgow: Glasgow Centre for Population Health, NHS Health Scotland and University of Aberdeen, www.gcph.co.uk/assets/0000/3828/Three-city_ survey_report_2013.pdf (accessed 22 July 2014) Warhurst, C. and Trebeck, K. (2013) 'In the Collective Interest: Job Quality', in E. Ben-Rafael, Y. Oved and M. Topel (eds), The Communal Idea in the 21st Century, Leiden, Boston MA: Brill

Watkins, K. (2013) 'Inequality as a Barrier to Human Development', paper presented at Kapuscinski Development Lectures, Stockholm School of Economics, Stockholm, 5 March 2013, http://kapuscinskilectures.eu/wpcontent/uploads/2013/03/Kevin_Watkins_ lecture.pdf (accessed 14 August 2014)
White, A. (2006) Transforming the Corporation, Great Transition Initiative Paper Series Frontiers of a Great Transition No 5, Boston MA: Tellus Institute, www.gtinitiative.org/ documents/PDFFINALS/5Corporations.pdf (accessed 23 December 2014)

Whittam, G. and Talbot, S. (2014) A Review of Social and Employee-owned Co-operative Business Models and their Potential to Reduce Poverty, UWS-Oxfam Partnership, Colaborative Research Report Series, Report No 2, Glasgow: Oxfam, University of West Scotland, http://uwsoxfampartnership.org.uk/wpcontent/uploads/2014/10/Co-op-BusinessModel-Report-final.pdf (accessed 23 December 2014)

Wilkinson, R. and Pickett, K. (2009) The Spirit Level - Why More Equal Societies Almost Always Do Better, London: Allen Lane

Williamson, J.; Driver, C. and Kenway, P. (2014) 'Introduction', in J. Williamson, C. Driver and P. Kenway (eds), Beyond Shareholder Value: The Reasons and Choices for Corporate Governance Reform, London: Trades Union Congress, New Policy Institute, SOAS, www.tuc.org.uk/sites/ default/files/BSV.pdf (accessed 23 December 2014) 